\title{
Correlations of condition factor and gonadosomatic, hepatosomatic and lipo-somatic relations of Leptodactylus macrosternum (ANURA: Leptodactylidae) in the Brazilian Semi-arid
}

\author{
MARCIO F. CHAVES ${ }^{1,2}$, FERNANDA C.M.A. TENÓRIO ${ }^{3}$, IGOR L.V.L. SANTOS ${ }^{2}$, CLOVIS J.C.L. \\ NETO $^{1}$, VALERIA W. TEXEIRA ${ }^{1}$, GERALDO J.B. MOURA ${ }^{4}$ and ÁLVARO A.C. TEXEIRA ${ }^{1}$ \\ ${ }^{1}$ Departamento de Morfologia e Fisiologia Animal, Universidade Federal Rural de Pernambuco, \\ Rua Dom Manoel de Medeiros, s/n, Dois Irmãos, 52171-900 Recife, PE, Brazil \\ ${ }^{2}$ Unidade Acadêmica de Biologia e Química, Centro de Educação e Saúde, Universidade Federal \\ de Campina Grande, Olho d'água da Bica, s/n, 58175-000 Cuité, PB, Brazil \\ ${ }^{3}$ Departamento de Histologia e Embriologia, Centro de Ciências Biológicas, Universidade Federal de \\ Pernambuco, Av. Prof. Moraes Rego, 1235, Cidade Universitária, 50670-901 Recife, PE, Brazil \\ ${ }^{4}$ Departamento de Biologia, Universidade Federal Rural de Pernambuco, Rua Dom \\ Manoel de Medeiros, s/n, Dois Irmãos, 52171-900 Recife, PE, Brazil
}

Manuscript received on April 26, 2016; accepted for publication on March 3, 2017

\begin{abstract}
The objective of this study was to assess variations of the condition factor (K1) in relation to the gonadosomatic- RGS and energy reserves (hepatosomatic - RWL and liposomatic - RFB relations) of Leptodactylus macrosternum and their relationship to climate variation in the Northeast of Brazil, Caatinga area, state of Paraiba. The animals were captured fortnightly through active collecting, between January and December 2013. Significant differences were observed in the monthly variations of K1, RGS and RFB indices in male and female L. macrosternum over the months of collection. In males, K1 showed no significant relationship with the other variables. In females, RGS values only show notable correlations with RWF and K1 values. K1 values showed significant correlations with all other weight and length ratios. Climate change in the HFOB region showed significant relationships with the variation of the indexes evaluated, with the exception of RWF. The variation of K1, RGS, RWL and RFB values over the months of collection as well as their relation with the local climatic variation, showed a brief reproductive activity for the species.
\end{abstract}

Key words: Anurans, fatty bodies, Northeast, reproduction, seasonality.

\section{INTRODUCTION}

The condition factor (K1) is a widely used index in animal biology studies. It indicates the degree of welfare of a population against the environment

Correspondence to: Marcio Frazão Chaves

Email: marciochaves@ufcg.edu.br
(Braga 1986). Therefore, the interpretation of this index reflects recent nutritional aspects or spending reserves in cyclical activities, which can relate to environmental conditions and reproductive aspects of the species (Vazzoler 1982). The variation of this index throughout the year can be used as additional data for the study of seasonal cycles of feeding and 
reproduction processes (Braga 1986, Lima-Junior et al. 2002, Satake et al. 2009).

Thereby, understanding the dynamics in terms of energy of a population, evaluating the interference of abiotic factors (Bojsen 2005, Duponchelle et al. 2007) as well as biotic interactions (Kortet and Taskinen 2004, Grorud-Colvert and Sponaugle 2006), providing information on the possible mechanisms that affect the reproductive processes of individuals in their areas of occurrence (Toledo et al. 2012).

The ratio between the weight of a structure for a given body size is a parameter that can also be used in determining ontogenetic morphological changes, providing important information on the reproductive status and/or nutrition of individuals in a population (Satake et al. 2009). The interpretation of the relationship between the weight of organs such as the liver, adipose tissue and gonads, could provide critical information on energy dynamics and the reproductive status of amphibians in Neotropical regions (Huang et al. 1997, Oliveira and Zieri 2005, Ebert et al. 2011, Franco-Belussi et al. 2012).

In areas of Caatinga, the limited amount of rainfall determines the reproductive pattern of amphibians. During the dry season, frog species present in this region have physiological and behavioral adaptations to temperature variations and lack of water in water bodies (Abe 1995). In these environments, the animals are reproductively active for two or three months during the year (Rodrigues 2003), a period determined by the increase in rates of rainfall in the region. Brown et al. (2011) in studies conducted in semi-arid areas showed that behavioral and physiological adjustments occur during different periods in the year. Animals with larger body sizes, growth rates and masses of fatty bodies coincide with the rainy season and reproductive period of the species (Brown et al. 2011).
Thus, knowledge of the reproductive patterns, the different factors and their relationship to the reproductive biology of anurans provide information that can complement the understanding of the structuring principles of the communities in their ecosystems (Bionda et al. 2011). Understanding these patterns is a primary and essential tool for further applied studies, focused on the conservation and management of biodiversity (Hockey and Curtis 2009).

This work adopts the species Leptodactylus macrosternum (Miranda-Ribeiro 1926) as a biological model for the interpretation of reproductive and energy dynamics of anurans in the Caatinga region of the state of Paraíba. Seeing it is a generalist species and well adapted to disturbed areas, L. macrosternum stands out for being a large frog in relation to other species occurring in Brazil; being used for production purposes as an alternative to the use of alien species in frog culture.

Therefore, the objective was to evaluate the correlation between the condition factor (K1) against the gonadosomatic relations - RGS and energy reserves (hepatosomatic - RWL and liposomal - RFB relations) of the model species as well as variations in these indexes over the months of sampling and their relations to the environmental parameters of the study area.

\section{MATERIALS AND METHODS}

\section{STUDY AREA}

The collections occurred in the Northeast of Brazil $\left(06^{\circ} 49^{\prime} 20\right.$ "S / $36^{\circ} 15^{\prime} 85^{\prime}$ 'W / $\left.667 \mathrm{~m}\right)$ in the state of Paraíba, with prior authorization from IBAMA Brazilian Institute of Environment and Renewable Natural Resources (44134 -1).

The study area (Fig. 1) consists of permanent and temporary lakes, situated in the central region of the Paraíba Agreste and a small area of the region of Curimataú. It features hot and dry climate with temperatures ranging between $17^{\circ}$ and $28^{\circ} \mathrm{C}$, an 


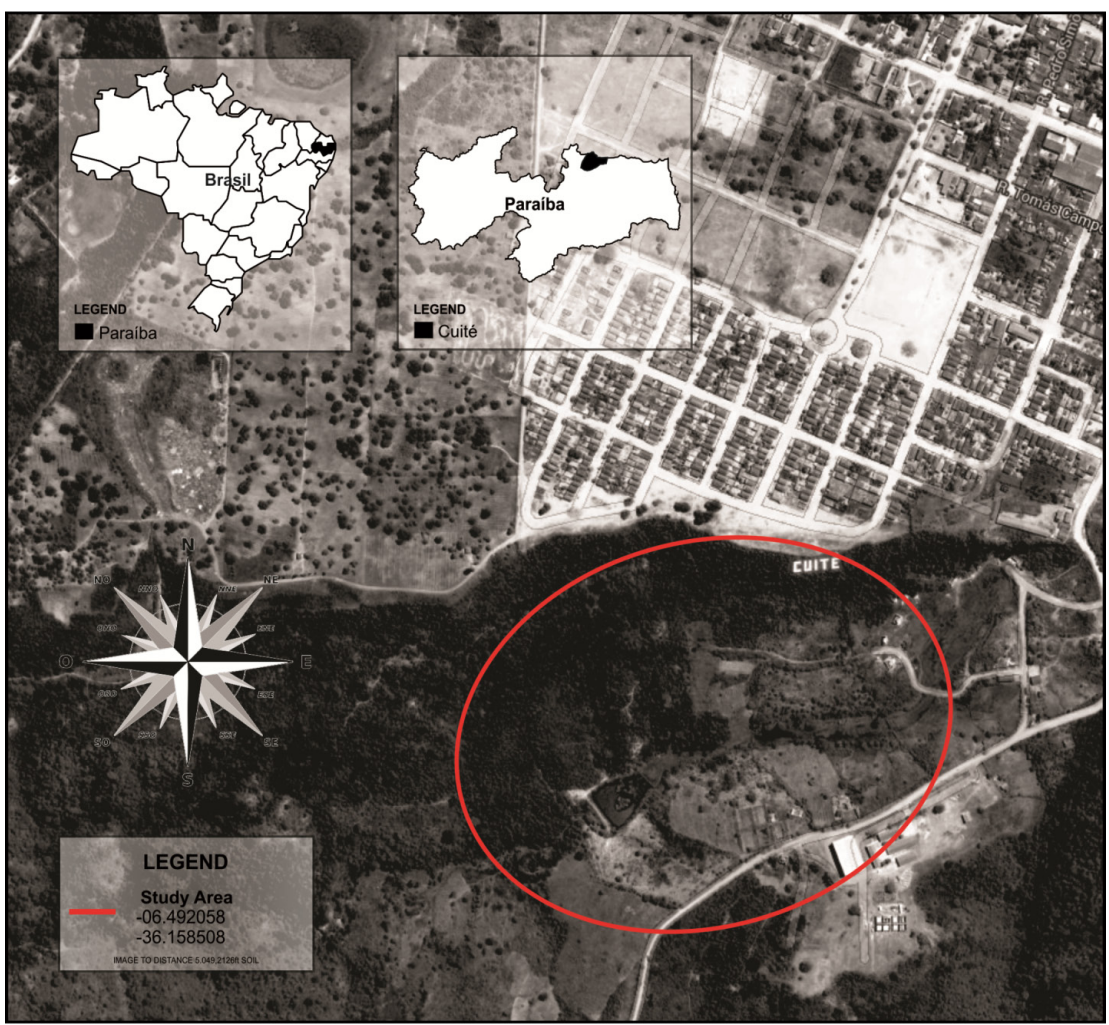

Figure 1 - Horto Florestal Olho d'Água da Bica (HFOB) location area, Cuité - Paraíba.

average monthly rainfall of $76.35 \mathrm{~mm}$ and relative humidity around 70\% (Abrantes et al. 2011).

\section{LABORATORY AND FIELD PROCEDURE}

For the execution of this work, night expeditions were carried out every 15 days from January to December 2013.

In LABAN - Amphibian Biosystematics Laboratory of the Federal University of Campina Grande, Cuité Campus - Paraíba, captured individuals were euthanatized with an overdose of Lidocaine $5 \%$ anesthetic, followed by the collection of biometric data such as total length $(\mathrm{cm})$, snoutvent length (SVL) and total mass (g). With the use of eye surgical materials, the gonads, liver and adipose bodies were removed and subsequently measured (greater length - mm). The measurements were performed using a digital caliper $(0.05 \mathrm{~mm})$ and then weighed $(\mathrm{g})$ on an analytical precision balance $(0.001 \mathrm{~g})$.

CALCULATION OF CONDITION FACTOR (K1), GONADOSOMATIC (RGS), HEPATOSOMATIC (RWL) AND LIPOSOMAL (RFB) INDEXES.

Body weight values (WT), and the weight of gonads (WG), liver (WL) and fatty bodies (WFB) were used for the calculation of gonadosomatic $[\mathrm{RGS}=\mathrm{WG}(100) / \mathrm{WT}]$, hepatosomatic [RWL = $\mathrm{WH}(100) / \mathrm{WT}]$ and liposomal [RFB = WFB (100) / WT] relationships (Vazzoler 1982).

The overall animals' condition factor (K1) was calculated by allometric method, from the expression $\mathrm{K} 1=\mathrm{w} / \mathrm{Lb}$, where $\mathrm{W}$ represents the total mass, and $\mathrm{L}$ the length of standard individuals. To estimate the value of coefficient $b$, a single equation of weight-length ratio was set $(\mathrm{W}=\mathrm{aLb})$ and applied to all collected individuals (LimaJunior et al. 2002). 


\section{CLIMATE DATA}

The monthly data of weather temperature $\left({ }^{\circ} \mathrm{C}\right)$ and rainfall $(\mathrm{mm})$ were obtained through the Executive Agency for Water Management (AESA 2014) database in the state of Paraíba.

\section{DATA ANALYSIS}

Data normality was tested by Shapiro-Wilk. The results for RGS, RWL, RFB and K1 variables over the months of collection were submitted to monthly comparisons, by applying the nonparametric Kruskal-Wallis test with post-hoc Dunn's test. The correlation between the variable K1 and RGS, RWL and RFB was tested by applying the Spearman correlation coefficient. The dependence of RGS, RWL, RFB and K1 variables and climatic variables (rainfall and temperature) in the HFOB area was tested by multiple linear stepwise regression analysis (backward). The 0.05 significance level was set for all of the above statistical treatments (Zar 1999).

\section{RESULTS}

Fifty-three individuals of Leptodactylus. macrosternum were collected (29 males and 24 females) over the months of May (9 samples - 5 males and 4 females), June (15 samples - 11 males and 4 females), July ( 8 samples - 3 males and 5 females), August ( 8 samples - 4 males and 4 females), November ( 7 samples - 4 males and 3 females) and December (6 samples - 2 males and 4 females) 2013, coinciding with the months presenting rainfall in the region. Between the months of January to April and September to October 2013, no individuals of L. macrosternum were found during field trips.

The value of angular coefficient of regression between weight and length (b) in the population of L. macrosternum sampled was 3.012 (Fig. 2).
The condition factor (K1) of male and female L. macrosternum over the months of collection showed significant differences in their values. The largest $\mathrm{K} 1$ values found in males of $L$. macrosternum were observed in December $(p=0.04)$ (Fig. 3). Regarding females, minor significant values were observed in July (Fig. 4). During the collection period, males had significantly lower values of gonadosomatic relation $(\mathrm{RGS})$ in June $(\mathrm{p}=0.04)$ (Fig. 3). The highest values of RGS found in males of $L$. macrosternum were observed in December $(p=0.03)$. Regarding females, the months of May $(p=0.02)$ and June $(p=0.05)$ showed the highest peaks of RGS (Fig. 4).

The monthly variation of hepatosomatic ratio (RWL), showed no significant differences between their values both for males (Fig. 3) and females (Fig. 4) in the months in which the animals were collected. Males and females of Leptodactylus macrosternum showed the highest values for RWL in July and December (Figs. 3 and 4). The monthly change in the values of liposomal ratio (RFB) between males and females of $L$. macrosternum showed significant differences among the sampled months. The lowest values observed for this parameter correspond in males for the months of June $(p=0.04)$ and August $(p=0.03)$ (Fig. 3). The largest values in the RFB of

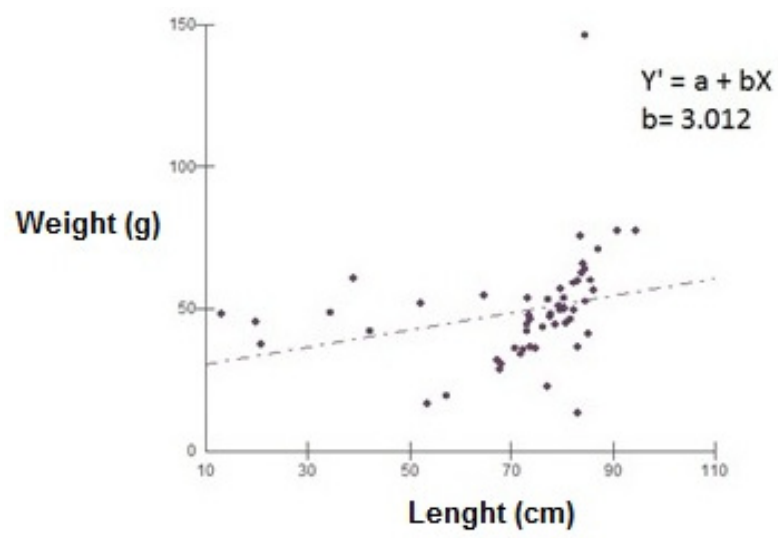

Figure 2 - Total weight ratio $(\mathrm{g}) /$ Length $(\mathrm{cm})$ of individuals collected of Leptodactylus macrosternum (L) (MirandaRibeiro, 1926) in the area of Horto Florestal Olho D'Água da Bica (HFOB), Cuité - Paraíba, from May to December 2013. 
L. macrosternum females were observed in August $(\mathrm{p}=0.05)$ and November $(\mathrm{p}=0.04)$. The month of December $(p=0.04)$ presented the lowest average values for this assessed parameter (Fig. 4).

Observing the results presented by the Spearman correlation test, the condition factor (K1) showed no significant relationship with the RGS, RWL and RFB variables throughout the collection period in males of $L$. macrosternum (Table I). However, in females, it is observed that the $\mathrm{K} 1$ values correlated positively with the RGS $(\mathrm{p}=0.03, \mathrm{r}=0.12)$ and RFB $(\mathrm{p}=0.05 ; \mathrm{r}=0.30)$ variables although having a negative correlation with the RWF variable $(p=0.05 ; r=-0.30)$ (Table I).

The variation of the condition factor (K1) of Leptodactylus macrosternum males showed no significant relationship with rainfall and temperature variation in the HFOB area. However, rainfall in the region showed significant relationships with

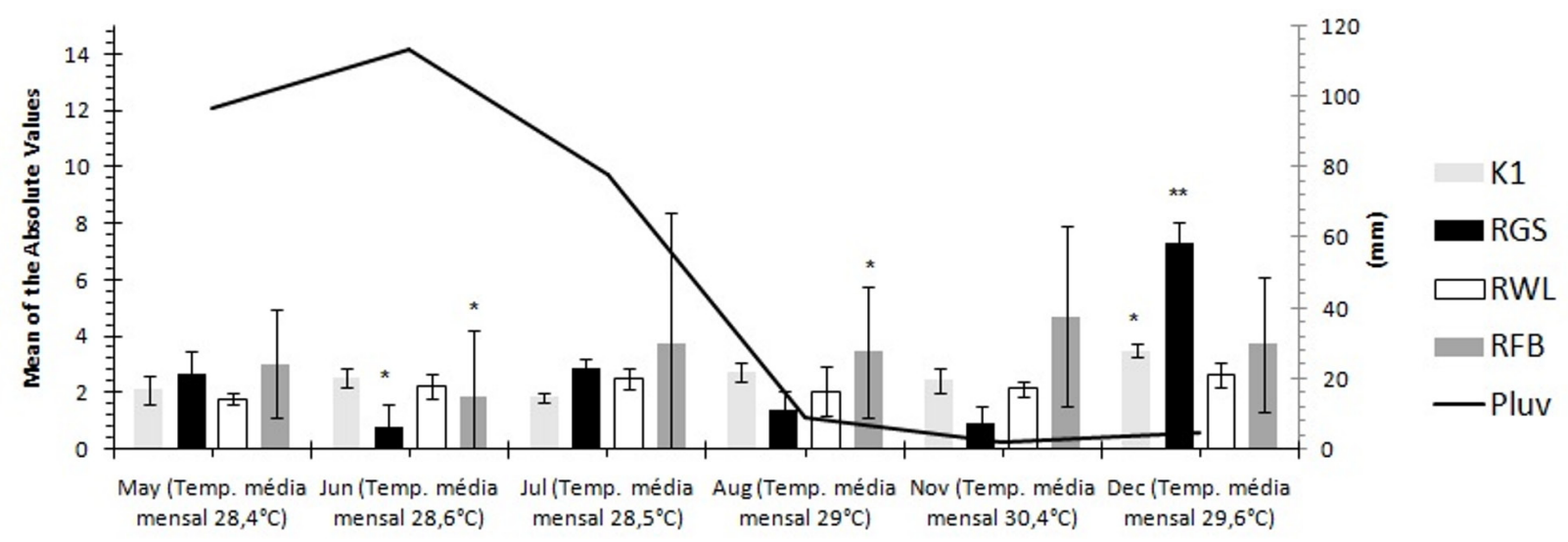

Figure 3 - Mean and standard deviation of the condition factor (K1), gonadosomatic relation (RGS), hepatosomatic ratio (RWL) and liposomal ratio (RFB) of male Leptodactylus macrosternum (Miranda-Ribeiro, 1926) and climatological variations-total rainfall $(\mathrm{mm})$ and temperature $\left({ }^{\circ} \mathrm{C}\right)$ collected in the area of Horto Florestal Olho D'Água da Bica (HFOB), Cuité - Paraíba, from May to December 2013. - (* indicates statistically significant differences using the Kruskal-Wallis test - p.

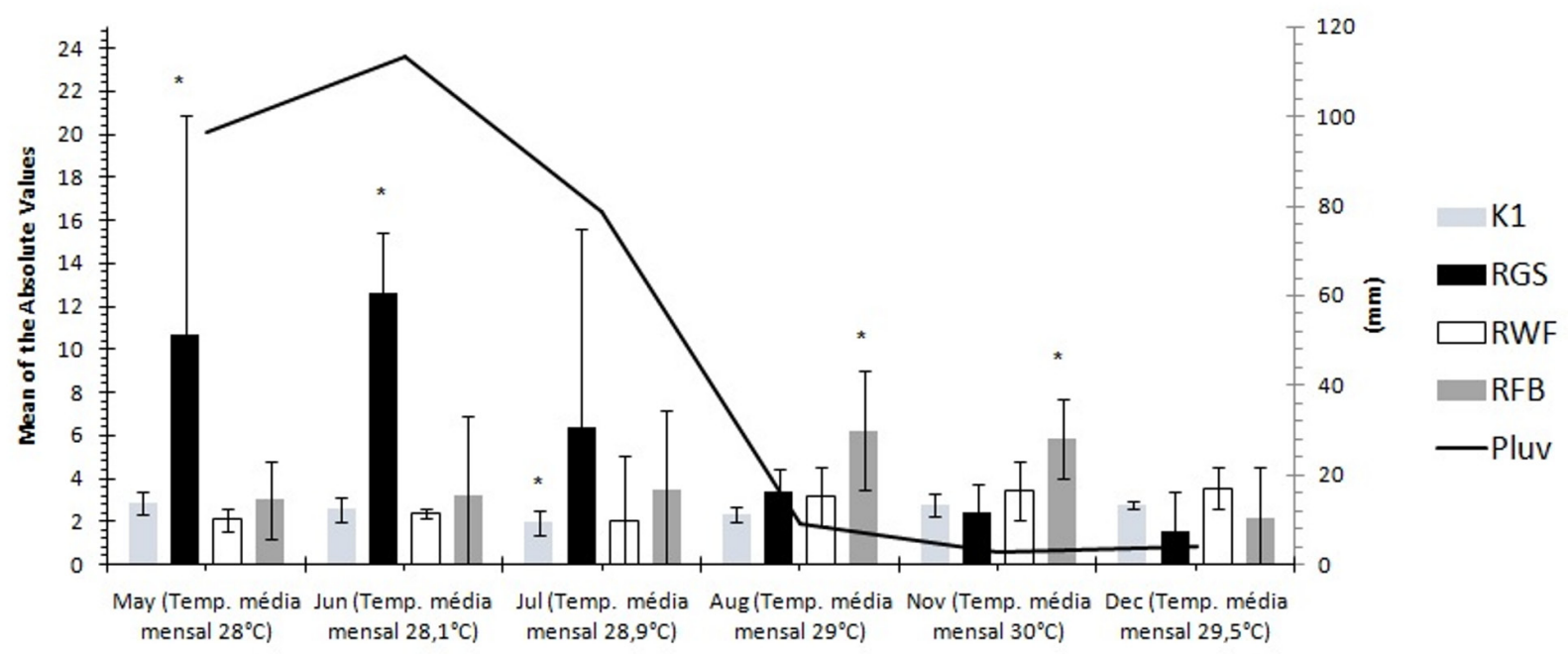

Figure 4 - Mean and standard deviation of the condition factor (K1), gonadosomatic relation (RGS), hepatosomatic ratio (RWL) and liposomal ratio (RFB) of female Leptodactylus macrosternum (Miranda-Ribeiro, 1926) and climatological variations-total rainfall $(\mathrm{mm})$ and temperature $\left({ }^{\circ} \mathrm{C}\right)$ collected in the area of Horto Florestal Olho D’Água da Bica (HFOB), Cuité - Paraíba, from May to December 2013. - (* indicates statistically significant differences using the Kruskal-Wallis test - p. 
TABLE I

Spearman's correlation coefficient comparing the ratio of condition factor (K1) with to gonadosomatic relation (RGS), hepatosomatic relation (RWF) and liposomal relationship (WFB) of males and females of the Leptodactylus macrosternum (Miranda-Ribeiro, 1926) species collected in the area of Horto Florestal Olho D’Água da Bica (HFOB), Cuité - Paraíba, from May to December 2013.

\begin{tabular}{ccccc}
\hline & \multicolumn{2}{c}{$\begin{array}{c}\text { Males } \\
\text { K1 }\end{array}$} & \multicolumn{2}{c}{ Females } \\
& & K1 \\
\hline & $\mathrm{p}$ & $\mathrm{r}$ & $\mathrm{p}$ & $\mathrm{r}$ \\
$\mathrm{RGS}$ & $\mathrm{ns}$ & - & 0.03 & 0.12 \\
$\mathrm{RWF}$ & $\mathrm{ns}$ & - & 0.05 & -0.30 \\
$\mathrm{RFB}$ & $\mathrm{ns}$ & - & 0.05 & 0.30 \\
\hline
\end{tabular}

${ }^{\text {ns }}$ no significant relationships.

the variation of $\mathrm{K} 1(\mathrm{p}=0.04)$ and WFB $(\mathrm{p}=0.05)$ in females of L. macrosternum. Furthermore, significant relationships were observed between the change of $\mathrm{K} 1(\mathrm{p}=0.04)$ with the temperature in the HFOB area among females of L. macrosternum. The variation in rainfall and temperature in the HFOB region showed significant relations with the change in RGS in males $(\mathrm{p}=0.02)$ and females ( $p=0.03$ ) of L. macrosternum over the months of collection. In contrast, no significant relationships were observed between the RWF variation and these climatic parameters in the study area (Table II).

\section{DISCUSSION}

The irregularity of rainfall as well as the formation and duration of water bodies, limit various aspects of life of anurans such as resource acquisition, accumulation of reserves and mainly, reproductive activity (Dayton and Fitzgerald 2001). The low occurrence of rainfall and its unpredictability in semi-arid environments can determine some physiological adjustments in anurans (Rossa-Feres and Jim 1994, Santos et al. 2007, Giaretta et al. 2008). In the rainy season, anurans may present a greater body size, a higher growth rate and increased accumulation of energy reserves as well
TABLE II

Relations between variables: condition factor (K1) gonadosomatic relation (RGS), hepatosomatic relation (RWF) and liposomal relation (WFB) with climate change (rainfall - Pluv and temperature - Temp.) of male and female Leptodactylus macrosternum (Miranda-Ribeiro, 1926) species collected in the area of Horto Florestal Olho D’Água da Bica (HFOB), Cuité - Paraíba, from May to December 2013.

\begin{tabular}{ccccc}
\hline & \multicolumn{2}{c}{ Males } & \multicolumn{2}{c}{ Females } \\
\hline & Pluv & Temp & Pluv. & Temp \\
\hline K1 & $b=-0,09^{\text {ns }}$ & $b=-0,68^{\text {ns }}$ & $b=0,08^{*}$ & $b=-1,76^{*}$ \\
RGS & $b=-0,04^{*}$ & $b=-1,80^{*}$ & $b=0,07^{*}$ & $b=-1,95^{\text {ns }}$ \\
RWF & $b=-0,01^{\text {ns }}$ & $b=-0,07^{\text {ns }}$ & $b=0,08^{\text {ns }}$ & $b=1,12^{\text {ns }}$ \\
WFB & $b=0,01^{\text {ns }}$ & $b=1,15^{\text {ns }}$ & $b=0,01^{*}$ & $b=1,25^{\text {ns }}$ \\
\hline
\end{tabular}

${ }^{\text {ns }}$ no significant relationships; $*$ significant relationships.

as increased gonadal development (Brown et al. 2011).

The Leptodactylus macrosternum studied here showed body weight increase proportional to the increase in body size, with an angular coefficient of regression between weight and length (b) 3.02 (Figure 2). According to Vazzoler (1996), animal populations showing angular variation coefficient of regression between weight and length (b) from 2.5 to 4.0 , exhibit an isometric growth pattern.

We observe a strong outlier present in the total weight axis of the sampled population of $L$. macrosternum (Figure 2). This outlier is strongly associated with the presence of animals with larger body masses concentrated in the period of higher rainfall in the region (May, June and July 2013), due to a greater accumulation of energy reserves and gonadal development, especially in females (Figure 4). In the rainy season, frogs may present a greater body size, a higher growth rate and greater accumulation of energy reserves as well as increased gonadal development (Brown et al. 2011).

The condition factor (K1) is an important indicator of the degree of health of an individual and its value reflects recent nutritional status and 
/ or spending of reserves in cyclical activities. This enables it to relate to environmental conditions and behavioral aspects of the species (Gomiero et al. 2010). In this study, females of the species L. macrosternum showed significant correlation between K1 values and RGS values, which may reflect greater energy expenditure for the production of gametes. In areas of Caatinga, anurans are breeding during two or three months in the year (Rodrigues 2003) and some species maintain foraging activity, consequently leading to accumulation of energy during the rest of the year (Duellman and Trueb 1999).

The highest peaks observed for K1 may be associated with a higher intensity of feeding activity of the Leptodactylus macrosternum species, with subsequent accumulation of body fat and carbohydrates in the liver, thus possibly being altered as a function in both intrinsic (organic reserves, gonadal development and size of the specimens) and extrinsic factors such as temperature, rainfall and food availability (Botelho et al. 2007). Therefore, the change in $K 1$ in the species may also be related to the availability and use of food by individuals during the months in which samples were collected.

The hypothesis of the $\mathrm{K} 1$ relationship with extrinsic factors may be corroborated by the relationship between its variation and climate variables observed in the $\mathrm{HFOB}$ region in females of L. macrosternum. In addition to this fact, are the relationships shown between the observed variations in rainfall and temperature in the region with the variation of RGS and WFB in females, and the ratio of the variation of RGS with rainfall in males of L. macrosternum in the HFOB region.

The result of the correlation test between the seasonal variation of $\mathrm{K} 1$ and RGS in $L$. macrosternum males observed in this study, showed that these two variables can present independent cycles, i.e. there is no significant association between them.

The liver is the second largest organ in the body and the largest gland. It is here that the nutrients absorbed in the digestive tract are processed and stored for use by other organs (Hipolito 2001). The arrangement of the liver tissue is directly related to the physiological characteristics of animals, such as ectotermia and reproduction (Bruslé and Anadon 1996), thus, RWF may also be used as an indicator of the reproductive period of L. macrosternum, correlated to other factors such as K1 and RGS. This index may be related to the mobilization of energy reserves necessary for the vitellogenesis process, reproduction or to prepare for a period of low food availability (Navarro et al. 2005). This confirms the result of the significant correlation of RGS and RWF values in L. macrosternum females observed in this study.

In anurans, fatty deposits are lipid bodies of great importance for the survival of these animals since they play key roles in metabolism, especially of energy reserves (Saidapur 1989, Saidapur 2001). In species with short periods of activities and related to the rainy season or warm periods, lipids need to be well equated between the spending on reproduction and reserves (Duellman and Trueb 1999). An example of this is that during the maturation of the ovules, females significantly increase the expense of gonadal adipose tissues, and their decrease can be observed during this period (Saidapur 1989, Saidapur 2001, Brown et al. 2011).

The evaluation of K1 values, RGS, RWF and WFB over the months where L. macrosternum specimens were collected, show a short reproductive activity for the species, probably concentrated between the months of May, June and December 2013. During the rainy season, anurans may present a greater body size, higher growth rate, greater accumulation of energy reserves and increased gonadal development. 


\section{ACKNOWLEDGMENTS}

We are grateful to Zuriel Rosemond for preparing the map. Special thanks to T.P. Souza, S. Kaene and T. Mauricio for the contributions to the manuscript. We thank ICMBio for the collection permit.

\section{REFERENCES}

ABE AB. 1995. Estivation in South America amphibian and reptiles. Braz J Med Biol Res 28: 1241-1247.

ABRANTES SH F, ABRANTES MMR, OLIVEIRA JCD, OLIVEIRA WM, HENRIQUES IGN, SILVA PF AND CHAVES MF. 2011. Fauna de anfíbios anuros em três lagoas da área de implantação do Horto Florestal, campus da UFCG, Cuité - PB. Rev Nord Zoo 5(2): 19-36.

AESA-AGÊNCIA EXECUTIVA DE ÁGUAS DO ESTADO DA PARAÍBA. 2014. Estações Agrometeorológicas. http://pcd.aesa.pb.gov.br/ (last access on 11/08/2014).

BIONDA CL, LAJMANOVICH RC, SALAS NE, MARTINO AL AND DI TADA IE. 2011. Reproductive Ecology of the Common South American Toad Rhinella arenarum (Anura: Bufonidae): Reproductive Effort, Clutch Size, Fecundity, and Mate Selection. J Herpetol 45(2): 261-264.

BOJSEN BH. 2005. Diet and condition of three fish species (Characidae) of the Andean foot hills - in relation to deforestation. Environ Biol Fishe 73: 61-73.

BOTELHO MLLA, GOMIER LM AND BRAGA FMS. 2007. Feeding of Oligosarcus hepsetus (Cuvier, 1829) (Characiformes) in the Serra do Mar State Park - Santa Virgínia Unit, São Paulo, Brazil. Braz J Biol 67(4): 741748.

BRAGA FMS. 1986. Estudo entre o fator de condição e relação peso-comprimento para alguns peixes marinhos. Rev Bra Biol 46(2): 339-346.

BROWN GP, SHILTON CM AND SHINE R. 2011. Measuring amphibian immunocompetence: validation of the phytohemagglutinin skin-swelling assay in the cane toad, Rhinella marina. Met Ecol Evol 2(4): 341-348.

BRUSLÉ J AND ANADON GG. 1996. The structure and function of fish liver. In: Munshi JSD and Dutta HM (Eds.), Fish Morphology. Oxford and IBH Publishing Co., PVT Ltd, New Delhi, p. 77-93.

DAYTON GH AND FITZGERALD LA. 2001. Competition, predation and distribution of four desert anurans. Oecologia 129: 430-435.

DUELLMAN WE AND TRUEB L. 1999. Biology of Amphibians, the Johns Hopkins University press, Baltimore and London, $670 \mathrm{p}$.

DUPONCHELLE F, LINO F, HUBERT N, PANFILI J, RENNO JF, BARAS E, TORRICO JP, DUGUE R AND NUÑEZ J. 2007. Environment - related life-history trait variations of thered-bellied piranha Pygocentrus nattereri in two river basins of the Bolivian Amazon. J Fish Biol 71: 1113-1134.

EBERT TA, HERNANDEZ JC AND RUSSELL MP. 2011. Problems of the gonad index and what can be done: analysis of the purple seaurch in Strongylo centrotuspurpuratus. Mar Biol 158: 47-58.

FRANCO-BELUSSI L, SANTOS LRS, ZIERI R, VICENTINI CA, TABOGA SR AND OLIVEIRA C. 2012. Liver Anatomy, Histochemistry and Ultrastructure of Eupemphix nattereri (Anura: Leiuperidae) During the Breeding Season. Zool Sci 29: 844-848.

GIARETTA AA, MENIN M, FACURE KG, KOKUBUM MNC AND OLIVEIRA FILHO JC. 2008. Species richness, relative abundance and habitat of reproduction of terrestrial frogs in the Triângulo Mineiro region, Cerrado biome, Southeastern Brazil. Iheringia, Série Zoologia 98(2): 181-188.

GOMIERO LM, VILLARES-JUNIOR GA AND BRAGA FMS. 2010. Relação peso-comprimento e fator de condição de Oligosarcus hepsetus (Cuvier, 1829) no Parque Estadual da Serra do Mar - Núcleo Santa Virgínia, Mata Atlântica, estado de São Paulo, Brasil. Biota Neotrop 10(1): 101-105.

GRORUD-COLVERT K AND SPONAUGLE S. 2006. Influence of condition on behavior and survival potential of a new lysettled coral reef fish, the blue head wrasse Thalassoma bifasciatum. Mar Eco Prog Series 327: 279288.

HIPOLITO M, LEME MCM AND BACH EE. 2001. Lesões anátomo-histopatológicas em rãs-touro (Rana catesbeiana Shaw, 1802) associadas à deterioração da ração. Arq Inst Biol 68(1): 111-114.

HOCKEY PAR AND CURTIS OE. 2009. Use of Basic Biological Information for Rapid Prediction of the Response of Species to Habitat Loss. Conserv Biol 23(1): 64-71.

HUANG WS, LIN JY AND YU JYL. 1997. Male reproductive cycle of the toad Bufo melanostictus in Taiwan. Zool Sci 14: 497-503.

KORTET R AND TASKINEN J. 2004. Parasitism, condition and number of front head breeding tubercles in roach (Rutilusrutilus L.). Ecol Fres Fish 13: 119-124.

LIMA-JUNIOR SE, CARDONE IB AND GOITEIN R. 2002. Determination of a method for calculation of Allometric Condition Factor of fish. Acta Scientiarum Maringá 24: 397-400.

NAVARRO RD, RIBEIRO FILHO OP, YASUI GS, MACIEL ECS AND SANTOS LC. 2005. Efeito do hormônio 17- $\alpha$-metil-testosterona nos índices somáticos de Rana catesbeiana. Zoo Trop 23: 319-325.

OLIVEIRA C AND ZIERI R. 2005. Pigmentação testicular em Physalaemus nattereri (Steindachner) (Amphibia, Anura) 
com observações anatômicas sobre o sistema pigmentar extracutâneo. Rev Bras Zoo 22(2): 454-460.

RODRIGUES MT. 2003. Herpetofauna da caatinga. In: Ecologia e conservação da caatinga. Universidade Federal de Pernambuco, ed. Universitária, p. 181-236.

ROSSA-FERES DC AND JIM J. 1994. Distribuição sazonal em comunidades de anfíbios anuros na região de Botucatu, São Paulo (Amphibia: Anura). Rev Bras Biol 54(2): 323334.

SAIDAPUR SK. 1989. Reproductive cycle of Amphibians: in Reprodutive cycles of Indian vertebrates. Saidapur SK (Ed), New Delhi, Allied Press, p. 165-223.

SAIDAPUR SK. 2001. Behavioral ecology of Anuran Tadpoles: The Indian scenario. Proc Indian Natn Sci Arcad (Pinsa) 67(06): 311-322.

SANTOS TG, ROSSA-FERES DC AND CASATTI L. 2007. Diversidade e distribuição espaço-temporal de anuros em região com pronunciada estação seca no sudeste do Brasil. Iheringia, Série Zoologia 97(1): 37-49.
SATAKE F, ISHIKAWA MM, HISANO H, PADUA SB, TAVARES-DIAS M AND TAVARES-DIAS M. 2009. Relação peso-comprimento, fator de condição e parâmetros hematológicos do dourado Saliminus brasiliensis cultivados em condições experimentais. Boletim de Pesquisa e Desenvolvimento. Ed 1. EMBRAPA, 22 p.

TOLEDO LF, GAREY MV, COSTA TRN, LOURENÇO-DEMORAES R, HARTMANN M AND HADDAD CF. 2012. Alternative reproductive modes of Atlantic forest frogs. $\mathrm{J}$ Etho 130: 331-333.

VAZZOLER AEAM. 1982. Manual de métodos para estudos biológicos de populações de peixes. Reprodução e crescimento. Brasília, Publicação do Conselho Nacional de Desenvolvimento Científico e Tecnológico, 106 p.

VAZZOLER AEAM. 1996. Biologia da reprodução de peixes teleósteos: teoria e prática. Maringá: NUPELIA, 169 p.

ZAR JH. 1999. Biostatistical analysis. New Jersey: Prentice Hall, 663 p. 